\title{
Claims-making in court cases on children: Religion, ethnicity, and culture in cases of Dutch minority families against the state
}

OÑATI SOCIO-LEGAL SERIES, VOLUME 11, ISSUE 4 (2021), 1066-1087: MiNORITY FAMILIES AND THE LAW: INTERACTIONS OF ETHNIC, RELIGIOUS, AND CULTURAL MINORITIES WITH LAW AND STATE INSTITUTIONS

DOI LINK: HTTPS://DOI.ORG/10.35295/OSLS.IISL/0000-0000-0000-1209

RECEIVED 20 DECEMBER 2019, ACCEPTED 14 JULY 2021

\section{IRIS SPORTEL* (D)}

\section{Abstract}

This paper focuses on cultural, religious, or ethnic claims made by family members in court cases against state institutions in the Netherlands. Based on an analysis of court judgements, I explore claims-making in cases regarding children from minority families in various fields of law. In the literature, such claims are often discussed in the context of the so-called cultural defence, where perpetrators of crimes make cultural claims to avoid or lessen punishment. However, family members may also make claims for exceptions of state policies, demand accommodation of particular practices, or to challenge discrimination by state institutions. The paper shows how Dutch courts are reluctant to engage with such claims, and often leave them out of court judgements entirely. I argue that this lack of engagement with cultural, religious, or ethnic claims should be understood in the context of general Dutch discourses of colour-blindness and assimilation of migrant minorities.

\footnotetext{
This paper is based on research funded by a VENI grant of NWO, the Netherlands Organization for Scientific Research. Part of the analysis of judgements was conducted during an Early-Career Fellowship of the Lichtenberg Kolleg, the Institute for Advanced Studies in the Humanities and Social Sciences, Georg-August University Göttingen. An earlier version of this paper was presented at the workshop Minority families and the law at the Oñati International Institute for the Sociology of Law in May 2019. I would like to thank the participants in the workshop, Betty de Hart, and the anonymous reviewers for their valuable comments. * Iris Sportel is an Assistant Professor at the Institute for Sociology of Law and the Centre for Migration Law of Radboud University Nijmegen, the Netherlands. She holds a PhD (2014) in sociology of law and gender studies from Radboud University. As a legal anthropologist, her research focusses on how individual actors -- ordinary people, legal professionals, and parties in court procedures -- deal with and experience law and legal institutions, especially in contexts of migration and transnationalism. She wrote Transnational Families and Divorce, Marriage, Migration, and Family Law (Palgrave Macmillan, 2016). Currently, she is working on a research project on Religion, culture, and ethnicity in court procedures on children from minority families, financed by a VENI grant from the Netherlands Organisation for Scientific Research (NWO). Email address: iris.sportel@ru.nl
} 


\section{Key words}

Claims-making in court; cultural defence

\section{Resumen}

Este artículo se centra en los argumentos culturales, religiosos o étnicos presentados por miembros de familias en casos judiciales contra instituciones del Estado, en Holanda. Basándome en un análisis de las sentencias judiciales, estudio la presentación de argumentos en casos relacionados con niños de familias de minorías en varios campos jurídicos. En la literatura, dichos argumentos suelen comentarse en el contexto de la así denominada defensa cultural, donde los autores de delitos presentan argumentos culturales para eludir o disminuir el castigo. Sin embargo, también los miembros de familias pueden presentar argumentos para excepciones de políticas estatales, para solicitar la aceptación de determinadas prácticas, o para aducir discriminación por parte de instituciones del Estado. El artículo muestra cómo los tribunales holandeses son reacios a aceptar esos argumentos, y a menudo los excluyen totalmente de las sentencias. Aduzco que esta falta de implicación con argumentaciones culturales, religiosas o étnicas debería entenderse en el contexto de los discursos generales de Holanda sobre la asimilación de minorías migrantes.

\section{Palabras clave}

Reclamaciones ante los tribunales; defensa cultural 


\section{Table of contents}

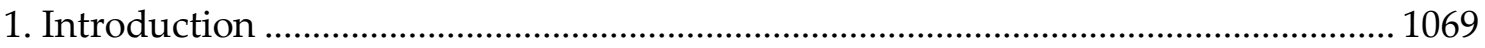

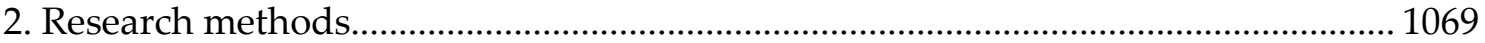

3. Theoretical framework: Cultural defence, cultural offence, and claims-making.... 1070

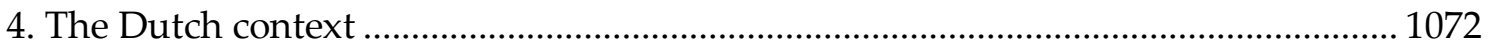

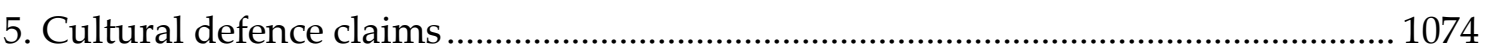

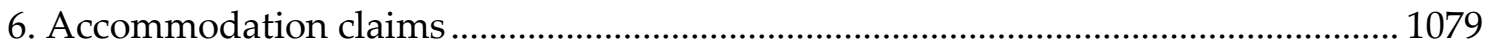

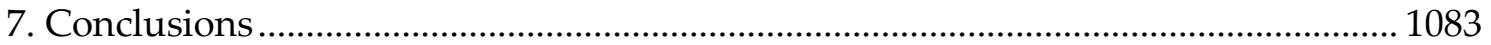

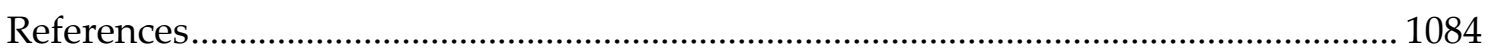

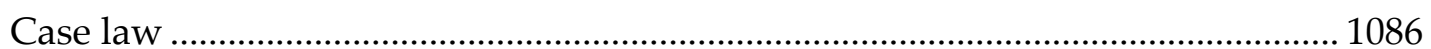




\section{Introduction}

This paper will focus on claims made by minority family members in court cases against state institutions. Especially for minority groups for which political change is less accessible, legal procedures against the state can be an important tool to influence their social position. In several European countries, legal claims made by minority family members regarding issues such as obligatory mixed swimming in schools (Switzerland) (Osmanoğlu and Kocabaş $v$ Switzerland, 2017) and providing halal or kosher food in schools (France) (Willsher 2017) have drawn media attention and sparked political and social debates. Most of the literature on claims-making by minorities in court cases seems to focus on such collective claims. Such claims are either made by minority groups mobilising the law collectively (Hobson and Lindholm 1997, Soysal 1998, Koopmans and Statham 1999, Bergman 2004, Larsson and Lindekilde 2009, Gleeson 2009, Hellgren 2012), or by strategic litigation of individual cases hoping to enforce a change of policy through the courts, a practice well-known from the US civil rights and feminist movements (Roe $v$ Wade, Brown $v$ Board of Education) as well from cases appearing for the European Court of Human Rights (Cichowski 2010).

Although collective claims seem to get most attention in the literature, people do not just make ethnic, religious, or cultural claims against the state with the aim of changing policies. Such claims are also made in individual cases, aimed at influencing the outcome of that particular case. A particular form of claims-making is often described in the context of criminal cases, as the so-called cultural defence, where perpetrators of crimes make religious, ethnic, or cultural claims to avoid or lessen punishment (e.g. Van Broeck 2001, Foblets and Renteln 2009, Renteln 2010, D'Hondt 2010, Cooke 2017). The issue of the cultural defence has sparked fierce normative debates among scholars and legal professionals, particularly in the US and, to a lesser extent, the UK. Often linked to issues such as violence against women, the cultural defence tends to be conceptualised as part of an ongoing moral debate on liberalism, multiculturalism, and group rights along the lines of Okin's famous book Is Multiculturalism Bad for Women - which has, indeed, a chapter on cultural defence (Okin 1999).

When making religious, ethnic, or cultural claims in court cases concerning their children, minority families may demand to be treated differently based on their background. However, such arguments are not limited to avoiding punishment. People may also ask for other exceptions of state policies, demand accommodation of particular practices, or challenge discrimination by state institutions. Therefore, in this article, I will use the broader analytical term of claims-making, which leaves more space to examine when and how claims are made and how courts react to such claims. Furthermore, rather than joining the normative debate over the cultural defence, I will take a socio-legal, empirical approach, aiming to explore claims-making in different types of cases, with a particular focus on issues regarding children.

\section{Research methods}

The main source for this paper is an analysis of judgements published in the online database of the Dutch judiciary, rechtspraak.nl. Courts select the judgments they publish in this database based on criteria such as public attention or legal interest. Higher courts 
publish relatively more of their caseload than courts of first instance. ${ }^{1}$ These publication strategies mean that cases in the database - and in this paper- are somehow special. Either because they went all the way to the highest courts, which is exceptional as it requires a lot of time, money, and dedicated legal support, or because the content of the case somehow stood out, which made the judges deciding the case select the judgement for publication.

I performed a systematic search in the rechtspraak.nl database, looking for cases in which the religious, ethnic, or cultural background of minority families played a role. I used broad keywords such as child, minor, culture, and religion as well as more specific terms such as circumcision, the names of a number of religious holidays, and vaccination. This search has yielded around 700 relevant judgements published between 2001 and 2018. For this paper, I focus on a sub-selection of 460 judgements that deal with conflicts between family members and state institutions, excluding, for example, divorce and other cases of intra-family conflict. This analysis of court judgements is part of a larger, ongoing study including interviews with judges; lawyers; welfare professionals and NGOs as well as interviews with parents and a study of court child protection files. Although the main focus of this paper will be on court judgements, the other parts of this project inform my analysis and will occasionally be referred to when particularly relevant.

Below, I will first present the theoretical framework for this article: on cultural defence, cultural offence, and claims-making. Then I will outline the Dutch context. Subsequently I will discuss two kinds of claims: defence claims and claims aiming at accommodation of specific practices. While equal treatment claims are also a relevant category, these claims will fall outside of the scope of this article. I will examine when and how such claims are made, and how the courts deal with them. Furthermore, through the example of parents making religious claims in the context of obtaining an exemption from compulsory education, I will demonstrate how legal procedures themselves also play a role in shaping litigants' claims. Contradictory to the scarcity of cultural, ethnic, or religious claims in other fields of law, the legal framework for exemptions from compulsory educations requires parents to make religious claims and courts to assess them.

\section{Theoretical framework: Cultural defence, cultural offence, and claims- making}

The concepts of cultural defence and cultural offence originate in criminal law. Van Broeck (2001) differs between cultural offences - mostly discussed by continental writers - and cultural defence, which has gained the attention of mostly common law authors. According to Van Broeck, a cultural offence is:

an act by a member of a minority culture, which is considered an offence by the legal system of the dominant culture. That same act is nevertheless, within the cultural group

\footnotetext{
${ }^{1}$ The results contain judgements published between the start of the online archive in 1999 and 2018. While only $1-2 \%$ of all lower court judgements are published on in the database, the percentage is $9-15$ for the higher courts. The highest courts publish all judgements. For more details on publication policies of courts, see https://www.rechtspraak.nl/Uitspraken-en-nieuws/Uitspraken/Paginas/Selectiecriteria.aspx.
} 
of the offender, condoned, accepted as normal behaviour and approved or even endorsed and promoted in the given situation. (Van Broeck 2001, p. 5)

Although the issue of the cultural defence has mostly discussed in criminal law cases (see for example: Van Broeck 2001, Foblets and Renteln 2009, D'Hondt 2010, Renteln 2010, Cooke 2017), similar defence arguments can also be made in other types of cases, especially child protection cases.

Although Foblets and Renteln (2009) see all cultural arguments made in court cases as cultural defence, such arguments are not limited to avoiding punishment. Family members do not just make such claims to defend themselves against accusations of child abuse in criminal or child welfare cases, or of failing to meet procedural standards, but also to challenge discriminatory practices by state institutions or demand particular forms of care when children are placed under state supervision. Analysing claimsmaking processes rather than defence enables drawing attention to a wide range of cases in which claims-making by minority families can play a role.

In her book Making Rights Claims. A Practice of Democratic Citizenship, Karen Zivi (2011) focusses on the process of making rights claims, which she sees as a performative act. According to Zivi, scholars tend to treat rights as objects that people have, and rights claims as statements that can be proven false or true and used instrumentally. However, a rights claim is more than just a statement of fact. Rather, rights claims are a performative practice of persuasion. By analysing rights claims as a performative act, Zivi draws attention to what is happening in and through the process of making a rights claim (Zivi 2011, pp. 11-12).

According to Zivi, what happens when someone makes a rights claim should be understood in the particular context the claims are made in. The process of claiming rights is governed by social rules and conventions. The effectiveness of a rights claim therefore tend to depends on the social norms referenced in the claim as well as whether the claims-maker references the proper social conventions for making such a claim (Zivi 2011). Feinberg and Narveson (1970) also see rights-claiming as a rule-governed activity. They differentiate between making claims in a performative sense, backed by legal power, and propositional claiming. Performative claiming is backed by legal power and actually makes things happen. You need to actually have a right before you can claim in in a performative sense. Propositional claiming does not usually have legal consequences. When claiming rights in a propositional way, you are insisting that you have particular rights and demanding that they are acknowledged (Feinberg and Narveson 1970).

In this article, I aim to draw attention to what happens when parties in court cases make ethnic, religious, or cultural claims in court cases vis-à-vis the state. Not all cultural, religious, or ethnic claims in the judgements I will analyse in this article are -strictly speaking- rights claims, as they are not always expressed in the language of rights. Nevertheless, these claims are made in legal procedures, and the process of making them is a performative practice of persuasion (Zivi 2011). Analysing claims-making as a process enables me to look at and compare different kinds of religious, ethnic or cultural claims as well as how courts react to and deal with these claims in their judgements. Zivi as well as Feinberg and Naverson see claims-making as an activity that is shaped by norms and rules in particular social contexts (Feinberg and Narveson 1970, Zivi 2011). 
For this article, Dutch migration history and Dutch discourses on religion, ethnicity, culture and race are particularly relevant.

\section{The Dutch context}

The Netherlands has a long history of migration and colonialism, as well as religious diversity. These histories continue to shape state policies on ethnic, religious, and cultural diversity. From the 1960s there has been significant labour migration from -in particular- Morocco and Turkey to the Netherlands, and Dutch-Moroccans and DutchTurkish are amongst the largest groups of migrant descent in the Netherlands. Both groups are predominantly Muslim. While this labour migration was initially seen as a temporary arrangement, during the 1970s there was a transition from labour migration to family migration, following changing economic circumstances. This shift was slowly reflected in Dutch migration policies from the 1980s, which started to focus on integration in Dutch society and equal rights for migrants (Bonjour 2006). A so-called minority-based approach was introduced.

These new migrant minority policies were organised in a way reminiscent of the Dutch religious pillarization system. According to Bonjour, these ethnic minority policies "clearly bore the marks of the Dutch political tradition of pluralism. The term 'minorities' itself referred to the traditional vision of Dutch society as composed of minorities" (Bonjour 2006). Since the late $19^{\text {th }}$ century, Dutch society was organised in denominational spheres, called "pillars", where Catholics, Protestants, and socialdemocrats -as well as smaller humanist and liberal groups- each had their own political parties, social institutions, trade unions, radio and television programming, and even shops. This tradition of pillarization also produced a religiously segregated child welfare and schooling system. While pillarization has been decreasing since the 1960s, denominational backgrounds are still visible in many of the institutions that deal with children. For example, one of the child welfare institutions that take custody over children after a court child protection order is a division of the Salvation Army. ${ }^{2}$ The 1980s and early 1990s approach to migrant minorities, aimed at integration while providing minority groups with possibilities to start their own social institutions was in line with this history.

From the 1990s onwards this minority-based approach, characterised by an ideology of multiculturalism and plurality started to shift. A harsher, more nationalistic and disciplinary discourse of assimilation slowly became dominant. This shift was reinforced by several incidents in the early 2000s: the aftermath of the attacks of September 11, 2001 in the US as well as two political murders in the Netherlands: on Dutch politician Pim Fortuyn (2002) and film-maker Theo van Gogh (2004). According to Prins and Saharso, this period is characterised by a backlash against the multiculturalism of the 1980s and 1990s (Prins and Saharso 2010). Public debates on migrant minorities shifted towards issues such as poverty and unemployment among migrant minorities and delinquency of young migrant men. In this highly gendered discourse, gender equality and sexuality form a central demarcation line between White Dutch and - especially - Muslim migrants, with Muslim women as a problematic group in particular need of

\footnotetext{
${ }^{2}$ Leger des Heils Jeugdbescherming \& Reclassering.
} 
emancipation (Roggeband and Verloo 2007, Prins and Saharso 2008, 2010, Wekker 2016, Sportel 2020).

In addition to labour migration, the Netherlands also have a history as a colonising power, with (former) colonies in the Caribbean, Suriname, and Indonesia. After decolonisation in the 1940s-1970s, many inhabitants of the former colonies came to the Netherlands. In her book White Innocence. Paradoxes of Colonialism and Race Gloria Wekker (2016) locates the origin of the place race takes in the Dutch "cultural archive" in this colonial history. Wekker summarises the Dutch discourse on race as following:

We are, thus, dealing in the Netherlands with a situation in which subjects and objects of racism keep each other in a delicate balance and where, until recently, the same evasive disruptive repertoires with regard to race were shared. It is a system in which both whites and blacks are overwhelmingly invested in denying and disavowing racism. I connect this syndrome, white innocence, to the strong Dutch attachment to a self-image that stresses being a tolerant, small, and just ethical nation, color-blind and free of racism and that foregrounds being a victim rather than a perpetrator of (inter)national violence. (Wekker 2016, p. 39)

Similar to other countries in the Global North, the Netherlands has a strong overrepresentation of minority families in the child protection and criminal systems, particularly migrant and postcolonial minorities. So-called non-Western migrant minority children are almost twice as likely to be under supervision of the child welfare authorities, and more than four times as likely to be in rehabilitation programs for having committed crimes. ${ }^{3}$ Nevertheless, in line with Wekker's observations, this is rarely discussed explicitly. Despite the overrepresentation of ethnic minority families in the child protection system and criminal law system, explicit ethnic, religious, or cultural claims are only present in a small part of Dutch court judgements concerning minority families and state institutions (see for similar observations about France and Belgium: Simon et al. 2019). Even when family members make such claims in court sessions in, for example, child protection cases, these claims often remain invisible in the final judgement. In many of the judgements and court files I studied, race, religion, or ethnicity is not mentioned explicitly, but rather remains implicit, absent, or is only hinted at occasionally.

Judgements in which explicit cultural, ethnic, or religious claims are present are therefore exceptional. In a series of interviews I did with family and youth judges, many shared similar observations. A "colour-blind" approach to family, child protection, and youth criminal cases was very common in the interviews with judges and there was a general reluctance to explicitly discuss culture, religion, or ethnicity, unless it was a "special case". In these special cases, representations of ethnicity, culture or religion tend to be either at the heart of the case or at the heart of the legal framework used to decide the case, the courts are forced to overcome their reluctance and explicitly reflect on representations of culture, ethnicity, or religion in their judgements. Analysing these exceptional cases provides a rare insight in the effects of cultural, ethnic, or religious claims made in courts, as well as in what happens when Dutch courts need to deal with

${ }^{3}$ CBS: jeugdbescherming en jeugdreclassering 2015. 
culture, ethnicity or religion. Below I will discuss claims made in judgements in two types of cases: cultural defence claims and accommodation claims.

\title{
5. Cultural defence claims
}

Most examples in the literature of cultural defences with regard to children concern parents who are accused of harming their children, fitting with van Broeck's description of "cultural offences" (Van Broeck 2001). In the court judgements I collected, I found 21 cases in which parents made such a cultural defence claim in criminal or child protection cases. However, such defence claims can also be made in other fields of law, such as migration or administrative law, for example when parents fail to meet certain standards such as providing information or filling out forms. If we take a closer look at these claims from the performative perspective of claims-making, it becomes clear that under the umbrella term cultural defence, different kinds of claims are being made, with different effects, and to which courts react in different ways. Below I will discuss four judgements from different fields of law: two criminal law cases, one migration law case, and one child protection case.

In the first case, one of the most "classic" examples of a cultural defence I have found, a father was accused of child abuse when his son's leg was fractured during a massage. The public prosecutor stated that the injury was the result of child abuse, while the father claimed that he accidentally caused the injury during a massage common for his ethnic group in Guinea. As it was clear that the son was hurt, the discussion in the court judgement focused on the intentions of the father, and whether he hurt his son deliberately. In the judgement, the court represented the father's claims as the massage being common for people from his cultural group:

\begin{abstract}
... The suspect has stated that during his youth in Guinea he saw both men and women giving massages to small children. From this cultural background he also massaged [the victim]. [...medical statement about injuries]. (...) The wife of the suspect, who was born in Cuba, has stated that massaging babies with oil is common in Guinea. She herself does not do this because she has a Cuban mother. Her father does come from Guinea, but from the files it does not follow that he is from the same tribal culture as the suspect. (ECLI:NL:RBMAA:2011:BP3069, 2011)
\end{abstract}

The prosecution rejected the claims of the father, arguing that "the story of the suspect considering the customs in his ethnic group is not believable". The prosecution also brought in a cultural expert on Africa to support this statement. The involvement of cultural experts in such cases is rare in the Netherlands. In all judgements I collected, I only found two other criminal law judgements in which a cultural expert was involved, one of which I will discuss below. ${ }^{4}$ With the expert's testimony, the prosecution aimed to counter the father's claim that the massage he executed was a common cultural practice. The full statement is not part of the judgement, only this reaction of the court:

Regarding the statement of prof. dr. [name] about massages in Africa the court can only establish that this religious anthropologist only paints a very common image of Africa

\footnotetext{
${ }^{4}$ However, reports from cultural experts are slightly more common in asylum cases. For an overview of the use of cultural expertise in different European countries see: https://culturalexpertise.net/, based on Livia Holden's EUROEXPERT research project. However, Holden's project uses a very broad definition of cultural expertise, which includes translators and specialised lawyers.
} 
as a continent and does not explain about custom with the tribe the suspect is a part of. (ECLI:NL:RBMAA:2011:BP3069, 2011)

The court acquitted the father of all charges, arguing that there is no proof that the father hurt his son on purpose, especially considering that his older son had had the same massages and never had any complications. The court also based their decision on a demonstration in the courtroom by the father:

During his trial, he demonstrated how he massaged [the victim]. The court has been able to see how the suspect indeed made certain motions [explanation of movements related to injury]. However, the court was not able to deduce that the suspect used excessive violence when making these motions. (ECLI:NL:RBMAA:2011:BP3069, 2011)

That the court reacted positively to the father's claims and that his cultural defence was successful, is rare. Only few of the criminal cases I found in which cultural defence claims were made these claims led to a complete acquittal.

The second example concerns a complicated case in which one of the suspects, a young adult woman from India, was brought to the Netherlands as a minor to do domestic work with an Indian family. She lived with her employers and their children, who were in the Netherlands legally, but they did not arrange for a residence permit for the young woman. Another Indian couple also lived in the house as domestic workers. This domestic worker couple had a baby girl, which the employers believed to be bewitched or possessed by an evil spirit. The baby was blamed for everything that went wrong in the lives of the employers' family and -on the orders of the employers- was physically punished for any negative event. The employers, the baby's parents, and the young woman all participated in the abuse. When the baby was one year and ten months old, the employers' son participated in a chess competition and lost several games that day, for which the baby girl was blamed and severely abused. She was admitted to a hospital with severe injuries, and died a few hours later. After her death, doctors found evidence of numerous old, untreated fractures and other injuries. The court decided that the suspects share the responsibility for killing the child, as not every instance of abuse could be linked to a specific suspect.

The case received extensive media attention and was appealed two times, all the way to the highest court. Although I did not have access to the judgement of the court of first instance, the judgements of the court of appeal and the court of cassation were made public. In the entire judgement of the court of appeal there is only a single mention of the cultural background of the young woman:

... the court takes into account that [the employers] exploited the suspect, who comes from the Indian culture, by, in short, letting the suspect stay in their residence in the Netherlands illegally, and employing her in their household; and that [employer 1] on [date] ordered the suspect to hit the victim and/or tie her up in order to control the evil spirit in [victim]. When evaluating psychological force majeure (...) the criteria considered are what can reasonably be required from people in civil life, in this case Dutch society. (...) Of the suspect could reasonably be required that, considering the breach of the (internationally applicable) absolute right to life of the toddler [victim] not yet two years old, she would have looked for ways to spare this victim's life, if necessary by facing the anger of [employers]. (ECLI:NL:GHSGR:2010:BK9410, 2010) 
Although the cultural background of the young woman is briefly mentioned in conjunction with her position as a domestic worker and victim of human trafficking, this judgement contains no explicit cultural arguments. In the brief rection to these claims quoted above, the court stressed that the criteria for force majeure should be based on Dutch norms. The appeal court sentenced the young woman to an imprisonment of five years, slightly less than the baby's parents and one of the employers, who received prison sentences of eight and six years respectively.

The lawyer of the young woman appealed the judgement in the highest court, de hoge raad, precisely on these grounds, claiming that "the court has neglected to take into account the cultural circumstances of the suspect in its judgement" (ECLI:NL:HR:2011:BP9394, 2011). From the judgement of the hoge raad it becomes clear that the lawyer has made extensive cultural defence claims in procedures in the lower courts; that these courts have ordered at least two reports by experts on the "cultural aspects" of the case; and that cultural arguments were also made in reports by psychiatrists assessing the suspect's mental health. However, none of this information was mentioned in the appeal court's judgement. In the judgement of the court of cassation, some of the cultural defence claims made by the suspect's lawyer are quoted directly. For example:

From these reports it becomes clear that [suspect] is in a situation incomparable to regular Dutch employees. Because of the caste system, subservience is an innate and fixed value. This also brings a profound loyalty. Loyalty and subservience we can hardly imagine. As is shown by the report, the relationship between employer and employee combines this loyalty with subservience and dependency. (...) As has been stated before, for Dutch people in general it is hard to empathise how a child - because that is what she was - has felt under the yoke of [employers]. (ECLI:NL:HR:2011:BP9394, 2011)

The lawyer combines these cultural claims with references to the suspect's mental health and the violence to which she has been subjected herself while living with her employers. He also refers extensively to other court cases where people have successfully appealed to force majeure because of pressure related to mental health issues and abuse. While the court of cassation quotes extensively from the lawyer's written plea, the court still dismissed the appeal, stating that, despite the cultural pressure, the young woman should have sought ways to save the victim's life. In this case, the cultural defence claims made by the young woman's lawyer were of a different nature than in the case of the father who accidentally hurt his son during a massage. The young woman did not deny having participated in abusing the baby girl, or having intended to hurt her, but her lawyer argued that her position and the cultural pressure she was under should have been taken into account (more) in the sentence.

The third example of cultural defence also concerns a child abuse case. However, this is not a criminal case but a child protection judgement. This is not uncommon in the Netherlands, where child abuse often is dealt with in the child welfare system rather than the criminal law system. However, different from criminal procedures, in these child protection procedures, family members do not aim to lessen or avoid sanctions directed against themselves, but rather to avoid protective measures such as being put under state supervision or the removal of their children. For example, in one case children were removed from their parents' home with an emergency care order. 
According to the children, they were abused by their parents, which involved putting chillies on the oldest child's genitals. The chillies had been found by paramedics in the underwear of one of the children when he sought help at the local police station. The court judgement shows that the parents made cultural defence claims during the subsequent court procedure on child protection measures:

The minor has had severe behavioural issues for quite some time, for which the parents have already sought help. Because the mother did not know what to do with him anymore, at some point she put ginger -not chili- in his anus. According to Ghanaian culture that would have a healing effect. This was the first time that such a thing happened, and the minor was perhaps so shocked that he went to the police, which is around the corner of their home. The parents do not deny that, occasionally, there have been some pedagogical slaps, but they deny that actual violence has been used against the children. (ECLI:NL:RBDHA:2013:7399, 2013)

These parents use cultural arguments to claim that their behaviour should not be seen as a form of violence, but rather as a culturally sanctioned act of desperate parents trying to use traditional healing on a child with behavioural issues. In this, their arguments were similar to those of the father who accidentally broke his son's leg. However, in this case, the court did not revoke the removal of the children.

Apart from the question whether chilies were actually used and the parents' statements that their way of raising their children stems from their culture, the children's judge takes this situation and the signs they observed from the children very seriously. As long as it is not certain that the children are safe at home, the children's judge considers it necessary and in the minors' best interest that they remain under care elsewhere for the duration of the investigation by the Child Protection Council.

As becomes clear from this quote, the court abstains from determining what happened exactly and whether or not the parents intended to use healing from their own cultural background or corporal punishment. Rather, fitting with a child protection case, they decide it is in the children's best interest to live away from their parents while the Child Protection Council investigates the case.

The final example concerns a migration law case. In 2004, an Afghan woman asked for family reunification with her three children and her elderly mother, who needed her care. The procedure took a long time, and only when the Dutch migration authorities asked for DNA tests the mother confessed that the eldest child was not her biological child, but was born from an earlier marriage of her late husband. Upon their marriage, the couple had decided to present the eldest child as their own. The Dutch rules for family reunification privilege biological nuclear family ties, meaning biological children, spouses or partners and - for minors - parents. While it is possible to have family reunification with non-biological (adopted) children or stepparents, these procedures are more difficult and additional conditions need to be met. ${ }^{5}$ After the mother's confession, the migration authorities decided no longer to believe any of the mother's statements, because she had lied about the eldest child being biologically hers. This means the authorities refused to believe the child was part of the mother's family, and

\footnotetext{
${ }^{5}$ Cultural and legal differences in what ties between people are recognised as valid family ties, are a wellknown topic in anthropological literature on migration law (see for example: Leinonen and Pellander 2014, Cole 2014, Chávez 2017, Drotbohm 2020).
} 
refused entry to the grandmother as well. The migration authorities also refused to conduct further DNA testing between the children to prove they were half-siblings. The mother appealed this decision, making cultural defence claims to defend against the accusation of lying:

Claimants argue that [the mother] sees [eldest child] as her biological child. The fact that [eldest child] is not her own child is a family secret that [the mother] only recently had to reveal. When [the mother] and [the father of eldest child] married, the entire family agreed to let [eldest child] pass for a real daughter of [the mother]. Reason for this agreement was the discrimination of stepchildren in Afghan culture. [The mother] was caught between the moral obligation to keep the family secret and the obligation to [the immigration services] to speak the truth. Until recently she chose to keep the family secret. That she has now been honest is not something her family is thankful for. ${ }^{6}$

The court mentions these cultural arguments put forward by the mother in the judgement, but does not engage with these claims. The court just states that not believing any of the mother's statements after discovering that the eldest child is not a biological child is too harsh. The court decides that the migration authorities should reconsider the case.

What then, can we learn when we look at this four cases from the perspective of claimsmaking as a performative practice of persuasion (Zivi 2011)? First of all, not all cultural defence claims do the same thing. While some claims are meant to differentiate between abuse and accidental harm -such as the father who hurt his son's leg during a massage, or the Ghanaian parents who claimed they used traditional healing on their son instead of punishment- other cultural defence claims were aimed at persuading the court that the pressure parents or caregivers were under should be seen as mitigating circumstances. The young Indian domestic worker and the Afghan mother fall in this category.

Secondly, as Zivi points out, rights claims should be understood in the particular context the claims are made in, which is governed by social rules and conventions. The effectiveness of claims therefore tend to depends on the social norms referenced in the claim (Zivi 2011). The case of the father who accidentally broke his son's leg is the only case where the court actually engages with the cultural claims made. In the other judgements, the courts only summarised the cultural arguments made, without engaging with the content of these claims, either to confirm their validity or question them critically. This is most clear in the case of the young Indian woman - where the court of appeal does not mention the content of the cultural claims at all and simply states that the young woman's behaviour should be measured against Dutch norms. This lack of engagement -or downright dismissal- of cultural claims demonstrates that these claims do not fit well with the social norms of Dutch courtrooms, which should be understood in the context of general Dutch discourses of colour-blindness and of assimilation and integration.

\footnotetext{
${ }^{6}$ ECLI:NL:RBSGR:2004:AO6633, Rechtbank 's Gravenhage, February 23, 2004. See for a similar case also: ECLI:NL:RBSGR:2009:BK3175
} 


\section{Accommodation claims}

The second category of claims are claims for accommodation of cultural, religious or ethnic practices. This category of claims is well-known from family law, where there is a broad literature on how courts deal -or should deal- with cultural or religious claims in divorce cases, child custody cases and other cases of intra-family conflict regarding children (see for example: Shah 2007, Rutten 2010, 2013, Bano 2012, Kulk 2013, Sportel et al. 2019). However, such claims are not limited to intra-family conflict. When children are placed under state supervision, parents can make similar claims regarding the care for their children. Especially when parents and children are not living together as a family, conflicts on aspects of care, such as medical procedures, vaccinations, or decisions over schooling can escalate and end up in court. However, when children are placed under supervision of the child welfare system, family members need to make these claims vis-à-vis institutions backed by the state rather than other private persons. ${ }^{7}$ Furthermore, also in families without state supervision, family members can make claims for accommodations or exemptions from state policies in other areas, especially regarding mandatory schooling.

In the first example, a judgement from 2007, a Dutch-Antillean mother of a boy who had been living with foster parents since he was born wanted her son to be circumcised, as was customary in her family, for reasons of hygiene and tradition. Moreover, the boy's father was of Surinamese-Hindustani origin, and male circumcision was part of his culture and religion. As the child was not living with her, the mother had to make a request to child welfare services to cooperate with the circumcision. Child welfare services refused, as they thought it would not be in the best interest of the child. They argued that the child should be able to decide for himself later whether he wanted to be circumcised, and that medical specialists do not agree on whether circumcision is more hygienic. The mother appealed this decision in court, arguing that child welfare services failed to take into account her wishes and cultural background. According to the law, child welfare services should consider "the religious disposition, belief, and cultural background of the client". ${ }^{8}$ In the judgement, the court used this legal framework, as well as the best interest of the child principle to analyse the mother's claims. First of all, the court argued that they could not consider the request for circumcision a religious request, as the mother was Catholic. As it had not been formally established who the boy's father was, the father's religion did not count. Subsequently, the court discussed the other arguments made by the mother:

Regarding the hygiene argument, the children's judge considers that, regardless of the medical views on the subject, it is not customary in the Netherlands to circumcise for medical reasons- unless there are special grounds. There is no evidence of special grounds of a physical nature. Regarding the cultural arguments, the court considers the following. The minor will grow up in the Netherlands, in a family where the

\footnotetext{
${ }^{7}$ In the Netherlands, children can be put under state supervision (ondertoezichtstelling) but remain living with their parents. In those cases, parents keep parental authority, but can be given instructions by the representative of child welfare services, who is also responsible for organising any assistance the family needs. To remove children from the care of their parents (uithuisplaatsing), an additional court order is necessary.

${ }^{8}$ Article 15 of the wet op de Jeugdzorg (law on youth care). This case is from 2007. In 2015, the legal framework for child protection has been reformed, a similar provision can now be found in art 2.3, lid 4 jeugdwet.
} 
circumcision of boys is not customary. For the minor, there is no chance of being raised by his mother. His future is in the foster family. The operation is not customary in the family and environment in which the minor grows up, which would make him stand out from other boys in his environment. This argument outweighs the mother's argument that he would be an exception among the male members of her family, especially as the minor is not actually part of that family and, for the time being, there is no prospect of contact with his mother's family. (ECLI:NL:RBZUT:2007:BB0833, 2007)

Because the mother's cultural and religious claims are at the heart of her case, the court needs to engage with these claims. The court rejected the mother's case. The child's best interest in this case is, according to the court, to fit in with his - Dutch - social environment, and therefore not to be circumcised. The court explicitly takes into account the boy's future and belonging, not with his birth mother and her family, but with his foster family and in Dutch society, where circumcision is not customary. There are two further interesting aspects in this judgement. First of all, there seems to be an implicit difference in weight between religious and cultural claims. The judgement carefully argues why this cannot be a religious claim, as the mother is Catholic and the father is not formally registered or in contact, and then goes on to dismiss the cultural claim. Secondly, child welfare services as well as the court seem to hold certain convictions of what "Dutch" society is. In this judgement, Dutch society seems to be conceptualised as exclusively white and native Dutch. By stating that circumcision is not customary in the Netherlands, the mother and her family, who are Antillean -a former Dutch colony- are excluded from the category "Dutch". In that regard, it is perhaps telling that this judgement is from the court in Zutphen, a small city in a region with relatively little ethnic diversity. It would be harder to argue that a circumcised boy would stand out in a big city like Amsterdam or Rotterdam, where over half of the children is of migrant descent, many from countries where circumcision is customary.

\section{Exemptions of compulsory education}

An important part of the judgements I found containing religious claims made by family members dealt with the topic of education. This is not surprising, as the Dutch constitution considers religious freedom in education a civic right (article 23). This does not only mean that anyone in the Netherlands has a right to found fully state funded schools based on their beliefs, but also that religious claims are one of the few ways for parents to get their children exempted from compulsory school attendance. ${ }^{9}$ In the Netherlands, all children aged 5-18 have to attend school, home-schooling is not recognised as an alternative. ${ }^{10}$ Parents or care-givers who do not send their children to school (as well as children over the age of 12 who fail to attend) can be prosecuted. However, based on the right to freedom of education, parents can apply for exemption of compulsory education when there is no school within reasonable commuting distance

\footnotetext{
${ }^{9}$ While this system has been controversial since the $19^{\text {th }}$ century, due to tensions with ideologies of nationbuilding and social cohesion (Rietveld-van Wingerden et al. 2003), it is still of great importance in understanding Dutch educational structure. Catholic, Islamic, Hindu, Waldorf, and Montessori schools are all state-funded. In 2020 only $31,4 \%$ of the primary schools was public. https://www.onderwijsincijfers.nl/kengetallen/po/instellingen/aantallen-instellingen-po

${ }^{10}$ With the exception of children who are unable to go to school because of illness or handicaps. Children age 16 and older can also be exempted if they already have a secondary school diploma.
} 
fitting with their beliefs. This means that parents who want to home-school their children, for whatever reason, will need to make religious claims to avoid prosecution. ${ }^{11}$

Of particular importance in how courts deal with religious claims for exemptions of compulsory education is the legal concept of richting (direction or denomination), which has been defined in jurisprudence as "a fundamental orientation, derived from certain religious or ideological beliefs". ${ }^{12}$ Based on claims by parents in court cases, richting has been established to not only encompass traditional religions, but also less well-defined beliefs as "holistic" or "Salafist" belief systems. While the court can judge whether parents' objections to local schools indeed concern the richting of the education, judges are not allowed to take into account the validity or strength of parents' beliefs. I will now discuss two examples of such cases, the claims parents made, and the response of the court. In terms of context, it is important to note that all these cases are criminal cases, in which parents who have initially been denied an exemption and still failed to register their children in a school are prosecuted.

In the first case, parents had applied for an exemption from compulsory education for their five-year-old son, based on the ground that the family was Jewish. The court prosecuted the mother. While there were several public schools as well as two Jewish schools in their city, the mother had a preference to educate their child at home. In the judgement, the court summarizes the mother's arguments, focusing on her objections to various schools, particularly the Jewish schools. The mother (represented by a lawyer) used three main arguments. First of all, the family raises their child in the Liberal Jewish tradition. One of the two Jewish schools in their city was Orthodox, and therefore not a good fit religiously. Secondly, while the second Jewish school did fit with their beliefs and values, the school would not accept the child. As the mother was not born Jewish, the child was not acknowledged by that community as Jewish and would therefore not be accepted as a student by the school. Furthermore, even if the school would be willing to make an exception to the admission policy, the mother still did not want her son attending this school, as she did not want him to attend a school where his identity is questioned. Thirdly, the mother also objected to her son attending a public school. She argues that Jewish identity is not or insufficiently developed there, or even hindered:

Jewish religion is present 24/7. Public schools do not keep Jewish dietary laws, and do not take into account Jewish points of view in teaching materials. This does not just concern subjects like history or biology, but also mathematics and languages. Jewish schools also pay attention to Jewish Holidays and the Jewish calendar. If [child] would go to a public school, it will continuously learn things he will have to unlearn at home. This is not in the best interest of the child. For example, in a public school the child will deal with Christmas trees, Santa Claus, Christmas songs and Saint Nicolas, which have no place in Jewish traditions. He could never eat anything offered to him because he follows Jewish dietary laws and he will always have to apply for special leave for Jewish Holidays. Therefore, [child] will always be a special case at a public school, which is a horrible experience for a child. (ECLI:NL:GHAMS:2016:410, 2016)

While the court accepted the mother's first argument as a valid objection based on religious (richting) concerns, it considered the second and third argument as being of a

${ }^{11}$ Another important condition is that parents apply for the exemptions before their child has ever attended school. See ECLI:NL:HR:2015:2577, September 9, 2015.

12 For example: ECLI:NL:GHARN:2008:BD3002, 2008. 
"practical and pedagogical nature" and therefore not sufficient grounds for granting the exemption. As the court argued:

The objections of the accused [the mother] concerning teaching materials, calendar, Christmas, Saint Nicolas, other holidays, and Jewish dietary rules are based on shortcomings in the practical organization of the school, for which, in consultation with the school, which in a pluralistic society like ours is open for children despite their nationality, social, cultural, or ideological beliefs, a solution should be possible. These objections certainly do not concern the richting (direction) of education. (...) The statements of the accused show a strong preference for educating (or letting the child be educated) the child at home. For example, she has argued that she can give her son a better education than schools offer. These objections, however, cannot be considered objections to the richting of education, but are objections to compulsory education as such. (ECLI:NL:GHAMS:2016:410, 2016)

The mother was convicted to a fine of 500 euros, part of which was suspended. In this case, the Amsterdam court of appeal seemed to hold the parents' strong preference for educating their child at home against them. Furthermore, it referred to an ideal picture of Dutch society as "pluralistic", welcoming and colour-blind, reminiscent of Wekker's white innocence (Wekker 2016). The mother appealed this judgement to the Hoge Raad, the highest court in the Netherlands. The Hoge Raad considered the argumentation in the judgement problematic, arguing that the mother's objections to public schools were not just practical but did concern the richting of education. The highest court referred the case back to another court for a retrial of the case (ECLI:NL:HR:2017:3111, 2017). This court acquitted the mother, stating that her concerns did consider the richting of education on public schools, and that the mother did not have to consider (Jewish) schools where her child would not be admitted (ECLI:NL:GHAMS:2018:1564, 2018).

In the second example, a father of a large Christian family was accused of keeping his children away from school without permission. The case concerned three of his children, aged $12-15 .{ }^{13}$ However, the local authorities had refused to prolong the exemption. The family used to be a member of the Old-Reformed Congregations in the Netherlands, a small protestant church; although at the time of the court hearing the father had left that church because he considered the behaviour of the church council to be "unscriptural". While there is a school in a nearby city which adheres to the same religious principles as the father, the father argues that it is "questionable whether [the school] practices absolute purity in observing the biblical truths as written in the Bible and the three forms of unity". In the judgement, the court briefly summarizes the father's list of arguments, which includes issues like the "worldly" decision-making style of the school board and its religious convictions; the fact that there are lessons in gymnastics; that some students use the internet; that the school has insurance policies; and how the school deals with other religions and denominations. Furthermore, the father objects to the fact that the family's exemption, which the family has had for many years -including for older siblings who are now adults- has suddenly been revoked. The court decides that in "all this material, to the judgement of the court, no sufficiently concrete and recognizable objection regarding the richting [direction] of education is pointed out." However, as the court "has taken into account that the accused has acted sincerely from his religious

\footnotetext{
${ }^{13}$ The total number of children is not in the judgement, but there appear to be several older siblings.
} 
beliefs, and that, for the accused, the case concerns a matter of principle", the father only gets a suspended fine.

Religious claims-making is encouraged or even required by the institutional structure of Dutch educational laws. This means that, different from the other cases discussed in this article, in these procedures religious claims fit well with the norms of the courts, and courts tend to engage with them extensively. As can be seen from both examples, the standards set by the courts to recognize objections as concerning the direction (richting) of education are quite high. Not only do parents need to frame their arguments explicitly as religious, even arguments which deal with the way religion is practiced in a particular school are not necessarily accepted as objections to its richting. In both cases, the parents were convicted, although in the first case this decision was later overturned by the highest court. Nevertheless, the tone of the two court judgements is different. While courts are legally not allowed to weigh the strength of religious convictions in such cases, the fact that the Jewish mother was a strong advocate of home-schooling made her religious beliefs suspicious, while the protestant father's religious convictions were explicitly confirmed as sincere. This did make a difference in the way the court dealt with their claims and can possible explain the differences in the sentences both parents were initially convicted to.

\section{Conclusions}

This paper focussed on cultural, religious, or ethnic claims-making of minority family members vis-à-vis state institutions. Based on an analysis of court judgements, I explored claims-making in different types of cases from various fields of law, with a particular focus on issues regarding children from minority families. Rather than simply labelling these claims as "cultural defence", seeing claims-making as a process enabled me to look at and compare different kinds of religious, ethnic or cultural claims as well as how courts react to and deal with these claims in their judgements. From the performative perspective of claims-making, it becomes clear that under the umbrella term cultural defence, different kinds of claims are being made, to which courts react in different ways.

Zivi as well as Feinberg and Naveson see claims-making as an activity that is shaped by norms and rules in particular social contexts (Feinberg and Narveson 1970, Zivi 2011). Religious, ethnic, and cultural claims should therefore be understood in the particular context the claims are made in, which is governed by social rules and conventions (Zivi 2011). In Dutch court judgements, the presence of cultural, religious, or ethnic claims in court judgements over children is rare. Even when such claims are made in courtrooms, they often do not end up in the written judgement. And even if such claims are present in the judgement, the court often does not actively engage with them or dismisses the claims by referring to "Dutch" social norms. As I argued in this paper, this lack of engagement with cultural, religious, or ethnic claims should be understood in the context of general Dutch discourses of colour-blindness and of assimilation and integration of migrant minorities.

At the same time, in criminal cases on exemptions from obligatory schooling, religious claims-making is encouraged or even required by the institutional structure of Dutch educational laws, which are grounded in a long history of religious pillarization. This 
means that in these procedures religious claims fit well with the norms of the courts, and courts tend to engage with them extensively. The example of exemptions from obligatory schooling also shows how cultural, religious, or ethnic claims can be shaped by the legal and institutional context as well as by litigants themselves.

\section{References}

Bano, S., 2012. Muslim Women, Divorce and Shari'ah Councils in Britain. In: R. Mehdi, W. Menski and J.S. Nielsen, eds., Interpreting divorce law in Islam. Copenhagen: DJØF, 181-221.

Bergman, S., 2004. Collective organizing and claim making on child care in Norden: Blurring the boundaries between the inside and the outside. Social Politics: International Studies in Gender, State E Society, 11(2), 217-246.

Bonjour, S. 2006. Who's in and Who's Out? The Postwar Politics and Policies of Family Migration in the Netherlands. Amsterdam: ESSHC Conference, 22-25 March.

Chávez, A.E., 2017. Intimacy at stake: Transnational migration and the separation of family. Latino Studies, 15, 50-72.

Cichowski, R., 2010. Civil society and the European court of human rights. In: J. Christoffersen and M.R. Madsen, eds., The European Court of Human Rights between Law and Politics. Oxford University Press.

Cole, J., 2014. Working mis/understandings: The tangled relationship between kinship, Franco-Malagasy binational marriages, and the French state. Cultural Anthropology [online], 29(3), 527-551. Available from: https://doi.org/10.14506/ca29.3.05 [Access 10 July 2021].

Cooke, T., 2017. Seeing Past the Liberal Legal Subject. Suomen Antropologi: Journal of the Finnish Anthropological Society [online], 42(3), 23-40. Available from: https://journal.fi/suomenantropologi/article/view/60988 [Access 10 July 2021].

D'Hondt, S., 2010. The Cultural Defense as Courtroom Drama: The Enactment of Identity, Sameness, and Difference in Criminal Trial Discourse. Law \& Social Inquiry [online], 35(1), 67-98. Available from: https://doi.org/10.1111/j.17474469.2009.01178.x [Access 10 July 2021].

Drotbohm, H., 2020. Care and reunification in a Cape Verdean family: Changing articulations of family and legal ties. Ethnography [online], 21(1). Available from: https://doi.org/10.1177/1466138118774071 [Access 10 July 2021].

Feinberg, J., and Narveson, J., 1970. The nature and value of rights. The Journal of Value Inquiry [online], 4, 243-260. Available from: https://doi.org/10.1007/BF00137935 [Access 10 July 2021].

Foblets, M.C., and Renteln, A.D., eds., 2009. Multicultural jurisprudence: Comparative perspectives on the cultural defense. Oxford: Hart.

Gleeson, S., 2009. From Rights to Claims: The Role of Civil Society in Making Rights Real for Vulnerable Workers. Law \& Society Review [online], 43(3), 669-700. Available from: https://doi.org/10.1111/j.1540-5893.2009.00385.x [Access 10 July 2021]. 
Hellgren, Z., 2012. Negotiating Social Membership: Immigrant Claims-making Contesting Borders and Boundaries in Multi-ethnic Europe. PhD thesis, Stockholm University. Acta Universitatis Stockholmiensis.

Hobson, B., and Lindholm, M., 1997. Collective identities, women's power resources, and the making of welfare states. Theory and Society, 26, 475-508.

Koopmans, R., and Statham, P., 1999. Challenging the liberal nation-state? Postnationalism, multiculturalism, and the collective claims making of migrants and ethnic minorities in Britain and Germany. American Journal of Sociology, 105(3), 652-696.

Kulk, F., 2013. Laverend langs grenzen. Transnationale gezinnen en Nederlands en islamitisch familie- en nationaliteitsrecht. Nijmegen: Wolf Legal.

Larsson, G., and Lindekilde, L., 2009. Muslim claims-making in context: Comparing the Danish and the Swedish Muhammad cartoons controversies. Ethnicities [online], 9(3), 361-382. Available from: https://doi.org/10.1177/1468796809337426 [Access 10 July 2021].

Leinonen, J., and Pellander, S., 2014. Court decisions over marriage migration in Finland: a problem with transnational family ties. Journal of Ethnic and Migration Studies, 40(9), 1488-1506.

Okin, S.M., 1999. Is multiculturalism bad for women? Princeton University Press.

Prins, B., and Saharso, S., 2008. In the spotlight. A blessing and a curse for immigrant women in the Netherlands. Ethnicities, 8(3), 365-384.

Prins, B., and Saharso, S., 2010. From toleration to repression: the Dutch backlash against multiculturalism. In: S. Vertovec and S. Wessendorf, eds., The Multiculturalist Backlash: European Discourses, Policies and Practices. London: Routledge, 92-110.

Renteln, A.D., 2010. Corporal punishment and the cultural defense. Law and Contemporary Problems, 73, 253-279.

Rietveld-Van Wingerden, M., Sturm, J.C., and Miedema, S., 2003. Vrijheid van onderwijs en sociale cohesie in historisch perspectief. Pedagogiek, 23(2), 97-108.

Roggeband, C., and Verloo, M., 2007. Dutch Women are Liberated, Migrant Women are a Problem: The Evolution of Policy Frames on Gender and Migration in the Netherlands, 1995-2005. Social Policy \& Administration, 41(3), 271-288.

Rutten, S., 2010. Protection of spouses in informal marriages by human rights. Utrecht Law Review [online], 6(2), 77-92. Available from: https://doi.org/10.18352/ulr.125 [Access 10 July 2021].

Rutten, S., 2013. The Netherlands. Applying Shari'a to family law issues in the Netherlands. In: M.S. Berger, M. Rohe and B.S. Turner, eds., Applying shari'a in the West: Facts, fears and the future of Islamic rules on family relations in the West. Leiden University Press. 
Shah, P., 2007. Rituals of Recognition: Ethnic Minority Marriages in British Legal Systems. In: P. Shah, ed., Law and Ethnic Plurality. Socio-Legal Perspectives. Leiden/Boston: Martinus Nijhoff, 177-202.

Simon, C., Truffin, B., and Wyvekens, A., 2019. Between norms, facts and stereotypes: the place of culture and thnicity in Belgian and French family justice. Studies in Law Politics and Society, 78, 113-129

Soysal, Y., 1998. Identity, Rights and Claims-making: Changing dynamics of citizenship in postwar Europe. Metropolis International Workshops Proceedings. Lisbon: LusoAmerican Development Foundation.

Sportel, I., 2020. Moroccan Family Law: Discussions and Responses from the Netherlands. Journal of Muslim Minority Affairs [online], 40(1), 67-83. Available from: https://doi.org/10.1080/13602004.2020.1741167 [Access 10 July 2021].

Sportel, I., Hart, B.D., and Kulk, F., 2019. Transnational Families Navigating the Law: Marriage, Divorce and Wellbeing. In: M. Tiilikainen, M. Al-Sharmani and S. Mustasaari, eds., Wellbeing of Transnational Muslim Families: Marriage, Law and Gender. London: Routledge.

Van Broeck, J., 2001. Cultural defence and culturally motivated crimes (cultural offences). European Journal of Crime, Criminal Law and Criminal Justice, 9, 1-32.

Wekker, G., 2016. White innocence: Paradoxes of colonialism and race. Durham: Duke University Press.

Willsher, K., 2017. Non-pork meals must be available for school lunch, rules French court. The Guardian [online], 28 August. Available from:

https://www.theguardian.com/world/2017/aug/28/non-pork-meals-must-beavailable-for-school-lunch-rules-french-court [Access 10 July 2021].

Zivi, K., 2011. Making rights claims: A practice of democratic citizenship. Oxford University Press.

Case law

ECLI:NL:GHAMS:2016:410. Gerechtshof Amsterdam, 4 February 2016 [online]. Available from: http://deeplink.rechtspraak.nl/uitspraak?id=ECLI:NL:GHAMS:2016:410 [Access 10 July 2021].

ECLI:NL:GHAMS:2018:1564. Gerechtshof Amsterdam, 8 May 2018 [online]. Available from: http://deeplink.rechtspraak.nl/uitspraak?id=ECLI:NL:GHAMS:2018:1564 [Access 10 July 2021].

ECLI:NL:GHARN:2008:BD3002. Gerechtshof Arnhem-Nijmegen, 6 June 2008 [online]. Available from: http://deeplink.rechtspraak.nl/uitspraak?id=ECLI:NL:GHARN:2008:BD3002 [Access 10 July 2021].

ECLI:NL:GHSGR:2010:BK9410. Gerechtshof 's Gravenhage, 19 January 2010 [online]. Available from: 
http://deeplink.rechtspraak.nl/uitspraak?id=ECLI:NL:GHSGR:2010:BK9410 [Access 10 July 2021].

ECLI:NL:HR:2011:BP9394. Hoge Raad, 6 December 2011 [online]. Available from: http://deeplink.rechtspraak.nl/uitspraak?id=ECLI:NL:HR:2011:BP9394 [Access 10 July 2021].

ECLI:NL:HR:2015:2577. 9 September 2015 [online]. Available from: http://deeplink.rechtspraak.nl/uitspraak?id=ECLI:NL:HR:2015:2577 [Access 10 July 2021].

ECLI:NL:HR:2017:3111. Hoge Raad, 12-12, 2017 [online]. Available from: http://deeplink.rechtspraak.nl/uitspraak?id=ECLI:NL:HR:2017:3111 [Access 10 July 2021].

ECLI:NL:RBDHA:2013:7399. Rechtbank Den Haag, 11 June 2013 [online]. Available from: http://deeplink.rechtspraak.nl/uitspraak?id=ECLI:NL:RBDHA:2013:7399 [Access 10 July 2021].

ECLI:NL:RBMAA:2011:BP3069. Rechtbank Maastricht, 11 January 2011 [online]. Available from: http://deeplink.rechtspraak.nl/uitspraak?id=ECLI:NL:RBMAA:2011:BU3869 [Access 10 July 2021].

ECLI:NL:RBSGR:2004:AO6633. Rechtbank's Gravenhage, 23 February 2004.

ECLI:NL:RBSGR:2009:BK3175 [online]. Available from: http://deeplink.rechtspraak.nl/uitspraak?id=ECLI:NL:RBSGR:2009:BK3175 [Access 10 July 2021].

ECLI:NL:RBZUT:2007:BB0833. Rechtbank Zutphen, 31 July 2007 [online]. Available from: http://deeplink.rechtspraak.nl/uitspraak?id=ECLI:NL:RBZUT:2007:BB0833 [Access 10 July 2021].

Osmanoğlu and Kocabaş v Switzerland, App no 29086/12. ECtHR, 10 January 2017. [online]. Available from:

http://hudoc.echr.coe.int/app/conversion/docx/?library=ECHR\&id=001170436\&filename=CASE $\% 20$ OF $\% 20$ OSMANO $\%$ C4\%9ELU\%20AND $\% 20 \mathrm{KOCAB}$ A \%C5\%9E\%20v.\%20SWITZERLAND.docx\&logEvent=False [Access 10 July 2021]. 